\title{
Inheritance of Resistance to a Lentil Strain of Pea Seed-Borne Mosaic Virus in Pisum sativum
}

\author{
R. Provvidenti and R. Alconero
}

In Pisum sativum, two independently inherited single recessive genes were found to confer resistance to the same pathotype of pea seed-borne mosaic virus from Ientil (PSbMV-L1). The gene sbm-2, present in the domestic cultivar Bonnevllle, was determined to be closely linked to mo, which conditions resistance to bean yellow mosaic virus and watermelon mosalc virus 2 and is known to be located In Plsum Ilnkage group 2. The second gene, sbm-3, was found in PI 347492, a bean yellow mosaic virus-susceptible line from India, and apparently is located in a different linkage group. Both genes, independently of each other, confer resistance to PSbMV$L 1$, but whether they are repetitive entities remains to be determined.

Pea seed-borne mosaic virus (PSbMV) wàs characterized by Musil in Czechoslovakia and by Inouye in Japan. ${ }^{15,18}$ In 1968 , this virus was found in the United States, $9,17,22$ and since then, its presence has been ascertained in several other countries. ${ }^{13}$

In searching for sources of resistance to PSbMV, Stevenson and Hagedorn, Baggett and Hampton, and Hampton and Braverman screened hundreds of accessions of Pisum sativum L. with the standard strain (PSbMV-ST) and found resistant germ plasm among foreign introductions. , $^{3,23}$ Hagedorn and Gritton determined that, in PI 193586 and PI 193835 accessions from Ethiopia, resistance was conferred by a single recessive gene $(\mathrm{sbm}){ }^{8}$

Recently, Goodell and Hampton and Ashby et al reported that PSbMV isolates from lentils (PSbMV-L) and from New Zealand peas (PSbMV-NZ) were unable to infect pea cultivars possessing mo, the gene for resistance to bean yellow mosaic virus (BYMV). ${ }^{2,624}$ Alconero et al demonstrated that resistance to PSbMV-P1 and PSbMVP4 (from pea), and to PSbMV-Ll (from lentil), was pathotype specific. ${ }^{1}$ Consequently, it appears that in $P$. sativum, there are distinct genetic entities for resistance to PSbMV, with each factor capable of controlling only a specific pathotype of the virus. Alone or in combination, these resistance factors were found in a number of plant introductions (PIs), mostly from. India and Ethiopia. ${ }^{1,11}$

With some exceptions, resistance to PSbMV-Ll in domestic cultivars, and in a number of Pls, was found associated with that to BYMV.119 The purpose of this study was to determine the inheritance of resistance to this pathotype of PSbMV in two accessions of $P$. sativum the cultivar Bonneville, which is resistant to BYMV, and PI 347492, which is susceptible. ${ }^{1}$

\section{Materials and Methods}

Pea accessions of foreign origin were obtained from the USDA Germplasm Resources, Northeast Regional Plant Introduction Station, Geneva, New York. Domestic cultivars were obtained from commercial sources. Viral isolates of PSbMV-L1 and BYMV were the same as those used in recent studies.119 The PSbMV-L was obtained from R. O. Hampton of Oregon State University. Genetic populations were derived by crossing the PSbMV-Ll-resistant Bonneville and PI 347492 with each other and with Ranger, which is susceptible to the aforementioned viruses.' Bonneville is known to be resistant to $B Y M V$, but susceptible to the PSbMV-ST; whereas PI 347492 is susceptible to BYMV, but resistant to three pathotypes of PSbMV.1,19 Populations of $F_{3}$ (Bonneville $\times$ Ranger) were used for linkage determination between mo and one of the genes for resistance to PSbMV-L1.

Test plants were mechanically inoculated when they had reached the two-leaf stage. Inoculum was prepared by macerating leaves of virus-infected Ranger plants with $0.05 \mathrm{M}$ phosphate buffer $\left(\mathrm{K}^{+}\right)$at $\mathrm{pH}$ 8.5. To avoid escapes, all plants received a second inoculation on the third leaf. 
Table 1. Segregation ratios of crows and backcross popalations of Pisam cafioum lines reoistant and susceptible to PSbMV-LI, a lentl straln of pea seed-borne moealc virus

\begin{tabular}{|c|c|c|c|c|}
\hline \multirow[b]{2}{*}{ Genotypes } & \multicolumn{2}{|c|}{ No. of plants } & \multirow[b]{2}{*}{ Exp. ratio } & \multirow{2}{*}{$\begin{array}{l}\text { Goodness- } \\
\text { of-fit } \\
\text { (probability) }\end{array}$} \\
\hline & Resistant & Susceptible & & \\
\hline $\begin{array}{l}\text { Bonneville } \\
\text { Ranger } \\
\text { PI } 347492\end{array}$ & $\begin{array}{r}50 \\
0 \\
38\end{array}$ & $\begin{array}{r}0 \\
50 \\
0\end{array}$ & & \\
\hline $\begin{array}{l}\text { Bonneville } \times \text { Ranger } \\
F_{1} \\
F_{2} \\
B C\left(F_{1} \times \text { Ranger }\right) \\
B C\left(F_{1} \times \text { Bonneville }\right)\end{array}$ & $\begin{array}{r}0 \\
24 \\
0 \\
41\end{array}$ & $\begin{array}{l}15 \\
84 \\
78 \\
48\end{array}$ & $\begin{array}{l}1: 3 \\
1: 1\end{array}$ & $\begin{array}{l}0.50 \\
0.47\end{array}$ \\
\hline $\begin{array}{l}\text { Ranger } \times \text { PI } 347492 \\
F_{1} \\
F_{2} \\
B C\left(F_{1} \times \text { Ranger }\right) \\
B C\left(F_{1} \times P I 347492\right)\end{array}$ & $\begin{array}{r}0 \\
20 \\
0 \\
44\end{array}$ & $\begin{array}{l}16 \\
68 \\
71 \\
52\end{array}$ & $1: 3$ & 0.64 \\
\hline
\end{tabular}

Plants that remained symptomless were considered resistant only if found free of systemic infection by enzyme-linked immunosorbent assay (ELISA) or virus recovery tests, using Ranger as the indicator host. An antiserum to PSbMV had been prepared for a previous study. ${ }^{1}$ In screening for resistance, 16 to 20 plants of each line were inoculated with each virus. All plants were maintained in an insect-free greenhouse at $25-30^{\circ} \mathrm{C}$.

\section{Results}

\section{Inheritance Studies for PSbMV-L1 Resistance}

Plants of Bonneville and PI 347492 remained free of local and systemic infection following inoculations with PSbMV-L1. Conversely, those of Ranger developed systemic green mottle, upward leaf cupping, and very short internodes. These severely stunted plants failed to set pods and eventually wilted and died prematurely. A similar reaction was noted in $F_{1}$ plants of (Ranger $\times$ Bonneville) and (Ranger $\times \mathrm{PI}$ 347492 ), demonstrating that resistance was inherited recessively. Recessive inheri- tance was confirmed in $F_{2}$ populations of (Ranger $\times$ Bonneville) and (Ranger $\times \mathrm{PI}$ three susceptible to one resistant. The data presented in Table 1 also show that plants of the backcross to the resistant parent segregated in a ratio of one resistant to one susceptible, whereas those of the backcross to the susceptible parent were all susceptible. Hence, it is evident that resistance to PSbMV-Ll in Bonneville and PI 347492 is monogenically recessive, but not necessarily conditioned by identical factors.

\section{Evidence of a Second Locus for Resistance to PSbMV-L1}

The $F_{1}$ plants from crosses between PSbMV-L1-resistant Bonneville with PSbMV-L1-resistant lines PI 193586, PI 193835, PI 347464, PI 347465, PI 347466, PI 347467 , and PI 347492 were all found to be susceptible to the vinus. This clearly indicated that the resistance factors present in Bonneville and in the aforementioned PIs were not allelic. Confirmation of two distinct and independently inherited genes for resistance to the same viral pathotype 347492 ), which segregated in the ratio of

Table 2. Reaction of $F_{1}, F_{2}$, and reciprocal backcross populations of crosses between Bonneville realstant to PSbMV-Ll and plant introductions (PI) aleo resistant to this virus

\begin{tabular}{|c|c|c|c|c|}
\hline \multirow[b]{2}{*}{ Genotypes } & \multicolumn{2}{|c|}{ No. of plants } & \multirow[b]{2}{*}{ Exp. ratio } & \multirow{2}{*}{$\begin{array}{l}\text { Goodness- } \\
\text { of-fit } \\
\text { (probability) }\end{array}$} \\
\hline & Resistant & Susceptible & & \\
\hline $\begin{array}{l}\text { (Bonneville } \times \text { PI 193586) } \mathrm{F}_{1} \\
\left(\text { Bonneville } \times \text { PI 193835) } \mathrm{F}_{1}\right. \\
\left(\text { Bonneville } \times \text { PI 347464) } \mathrm{F}_{1}\right. \\
\left(\text { Bonneville } \times \text { PI 347465) } \mathrm{F}_{1}\right. \\
\left(\text { Bonneville } \times \text { Pl 347467) } \mathrm{F}_{1}\right. \\
\left(\text { Bonneville } \times \text { PI 347492) } \mathrm{F}_{1}\right. \\
\left(\text { Bonneville } \times \text { PI 347492) } \mathrm{F}_{2}\right. \\
\left(\text { Bonneville } \times \text { PI 347492) } \mathrm{F}_{1}\right. \\
\times \text { Bonneville } \\
\left(\text { Bonneville } \times \text { PI 347492) } \mathrm{F}_{1}\right. \\
\times \text { PI 347492 }\end{array}$ & $\begin{array}{r}0 \\
0 \\
0 \\
0 \\
0 \\
0 \\
62 \\
\\
28 \\
\\
\end{array}$ & $\begin{array}{r}6 \\
6 \\
6 \\
6 \\
5 \\
10 \\
85 \\
\\
34\end{array}$ & $7: 9$ & $\begin{array}{l}0.70 \\
0.46\end{array}$ \\
\hline
\end{tabular}

was obtained from the segregation of $F_{2}$ (Bonneville $\times$ PI 347492) and reciprocal backcross populations. As shown in Table $2, F_{2}$ plants segregated in the ratio of seven resistant to nine susceptible, whereas a segregation of one resistant to one susceptible was obtained from populations of both backcrosses. Thus, it can be concluded that the single recessive genes for resistance to PSbMV-L1 in Bonneville and PI 347492 are independently inherited, but have the identical function of controlling the same pathotype of the virus.

\section{Linkage Studies}

A close linkage was found in Bonneville between mo and sbm-2. The data presented in Table 3 show that $F_{3}$ families of Bonneville $\times$ Ranger that were resistant or susceptible to PSbMV-L1 were also resistant or susceptible to BYMV. Families that segregated for PSbMV-L1 also segregated for BYMV.

\section{Comparative Studies with PSbMV-L and PSbMV.L1}

These two isolates derived from infected seeds of lentil (Lens culinaris), but PSbMV- $L$ caused milder symptoms in susceptible pea cultivars than PSbMV-L1. However, pea and lentil lines resistant to one of these isolates were determined to also be resistant to the other. ${ }^{1}$ In comparative tests, the cultivars Ranger and Alaska, previously reported to be resistant to PSbMV-L, ${ }^{10}$ were found to be susceptible to both isolates.

\section{Discussion}

Hagedorn and Gritton assigned the symbol $s b m$ to the single recessive gene conferring resistance to PSbMV-ST, the first categorized pathotype of PSbMV. ${ }^{8}$ Our study has demonstrated that the resistance to a second pathotype PSbMV-L1 is also monogenically recessive, but conditioned by two distinct and independently inherited genetic factors. Hence, we propose the following symbols: (1) sbm-l for sbm, which was reported by Gritton and Hagedorn to be situated in Pisum linkage group 6 ; (2) sbm-2 for the gene found in Bonneville and conferring resistance to PSbMV-Ll ${ }^{7}$ This gene was demonstrated (Table 3) to be closely linked to $m o$, thus, it is located in Pisum linkage group $2 ;^{16}$ and (3) $s b m-3$ for the gene found in PI 347492 , also conferring resistance to PSbMV-L1, but inherited independently from $s b m-2$ (Table 2). Thus, sbm-l, sbm-2, and $s b m-3$ are not allelic because they belong to different linkage groups. The two factors, 
Table 3. Reaction to PSbMV-Ll and BYMV in 45 F, famllies of the cross Bonnevlle $\times$ Ranger

\begin{tabular}{|c|c|c|c|c|c|}
\hline \multirow[b]{2}{*}{ Viruses } & \multicolumn{3}{|c|}{ No. of families } & \multirow[b]{2}{*}{ Exp. ratio } & \multirow{2}{*}{$\begin{array}{l}\text { Goodness- } \\
\text { of-fit } \\
\text { (probability) }\end{array}$} \\
\hline & Resistant & $1(\mathrm{R}): 3(\mathrm{~S})$ & Susceptible & & \\
\hline $\begin{array}{l}\text { BYMV } \\
\text { PSbMV-L1 }\end{array}$ & 10 & 22 & 13 & $1: 2: 1$ & 0.81 \\
\hline
\end{tabular}

a For each family, 16 plants were tested with BYMV and 16 with PSbMV.

$s b m-2$ and $s b m-3$, appear to have the same function of conferring resistance to the same pathotype of PSbMV, but whether they are duplicate or repetitive genes remains to be determined. An analysis of the sequence homologies of these two genes eventually will clarify this point.

A very recent study has demonstrated that the gene $c y v$ for resistance to clover yellow vein virus (CYVV) is also closely linked to $m o .^{19}$ Thus, it is evident that on the second chromosome of Bonneville, and possibly in many other domestic BYMVresistant cultivars, there are three very closely linked genes: mo, for BYMV and WMV-2, ${ }^{21}$ cyv for CYVV, ${ }^{19}$ and $s b m-2$ for PSbMV-L1. Additional evidence has suggested that factors for resistance to pea mosaic virus (PMV), ${ }^{4}$ and the NL-8 strain of bean common mosaic virus (BCMVNL8), ${ }^{20}$ may be closely linked to mo. Hence, it appears that at the mo locus there is a cluster of genes that, during breeding for resistance, are transferred as a single unit.

From a breeding point of view, this represents an ideal situation, because viral testing could be limited to one of these six viruses. However, adequate testing for multiresistance is necessary and strongly recommended. Although most of the domestic cultivars resistant to BYMV are resistant to BCMV-NL8, CYVV, PMV, PSbMV$L 1$, and WMV-2, there are lines that differ in the number of resistance factors present in them. For example, PI 391630 from China is resistant only to BYMV; PI 269818 from the USSR is resistant to BYMV and PSbMVL1, but susceptible to CYVV; and a number of lines from India and Ethiopia are susceptible to BYMV, but resistant to CYVV and PSbMV-L1. ${ }^{19}$ Even when two pea lines are resistant to the same isolate of a given virus, testing is advisable because the progenies of their cross may segregate for resistance. In this study, we have established that both Bonneville and PI 347492 are equally highly resistant to PSbMV-Ll, but they possess two distinct genes situated in different linkage groups. In the soybean, Buss et al reported that resistance to an isolate of peanut mottle virus in the cultivars Arksoy, Dorman, York, and Shore is conditioned by a single dominant gene, which is inherited independently of a second dominant gene present in the cultivar CNS. $^{5}$ In the pea, Provvidenti found that there are two single recessive genes (cyv and $c y v-2$ ), which, independently of each other, are able to confer resistance to the same isolate of CYVV. ${ }^{19}$ Thus, without adequate testing, susceptible lines can easily derive from resistant parents. have been characterized using differential pea lines with a major emphasis on symptomatology. ${ }^{14}$ For pea breeding purposes, isolates of PSbMV should, instead, be classified on the basis of genes able to control them (pathotype groups). A pathotype is defined as an entity of a given virus that is controlled by a specific genetic factor in a given plant species or family. However, a pathotype may include a range of variants differing in virulence. For example, PSbMV-L and PSbMV-L1 can be easily differentiated by the intensity of symptoms that they incite in susceptible pea genotypes, but because both isolates are controlled by $s b m-2$ or $s b m-3$, they belong to the same pathotype group.

\section{References}

1. Alconero, R, R Provvidenti, and D. Gonsalves. Three pea seed-borne mosaic virus pathotypes from pea and lentil germ plasm Plant Dis 70:783-786, 1986.

2. Ashby, J. W., J. D. Fletcher, W. A. Jermyn, and D. Goulden. Some properties of a strain of pea seed-borne mosaic virus isolated from pea in New Zealand. N.Z. J. Exp. Agr 14:209-213, 1986.

3. Baggett, J. R., and R O. Hampton. Plant introduction lines of Pisum sativum resistant to pea fizzle top diseases. Plant Dis. Rep. 56:131-132, 1972.
A number of isolates or strains of PSbMV
4. Barton, D. W., W. T. Schroeder, R. Provvidenti, and W. Mishanec. Clones from segregating progenies of garden pea demonstrate that resistance to $B V 2$ and PV2 is conditioned by the same genotype Plant Dis. Rep. 48:353-355, 1964.

5 Buss, G. R., C. W. Roane, S. A. Tolin, and T A. Vinardi. A second dominant gene for resistance to peanut mottle virus in soybeans Crop Sci. 25:314-316, 1985.

6. Goodell, J J., and R. O. Hampton. Interaction of Pisum genes sbm and mo with pea seed-borne mosaic virus (PSbMV): Symptom expression and immunity to three variant strains. Phytopathology 73:789 (Abstr.), 1983.

7. Gritton, E T., and D. J Hagedorn Linkage of the pea genes sbm and wlo in peas. Crop Sci. 15:447-448, 1975

8. Hagedorn, D. J., and E. T. Gritton. Inheritance of resistance to the pea seed-borne mosaic virus. Phytopathology 63:1130-1133, 1973.

9. Hampton, R. O. Characteristics of virus particles associated with a seed-borne pea fizzle top disease. Phytopathology 59.1029 (Abstr.), 1969.

10. Hampton, $R$ O. Incidence of the lentil strain of pea seed-borne mosaic virus as a contaminant of Lens $\mathrm{Cu}$ linaris germ plasm. Phytopathology 72:695-698, 1982.

11. Hampton, R. O. Geographic origin of pea seedborne mosalc virus: A hypothesis. Pisum Newsl. 18: 22-26, 1986.

12. Hampton, R. O., and S. W. Braverman. Occurrence of pea seed-borne mosaic vinus and new vinus-immune germ plasm in the Plant Introduction collection of $\mathrm{Pi}$ sum sativum. Plant Dis. Rep. 63:95-99, 1979.

13. Hampton, R O., and G. I. Mink Pea seed-borne mosaic virus. C.M.I./A.A.B. Description of Plant Vlnuses, No 146,1975

14 Hampton, R. O., G. I. Mink, L. Bos, T. Inouye, M Musil, and D. J. Hagedorn. Host differentiation and serological homology of pea seed-borne mosaic virus isolates. Neth. J. Plant Pathol. 87:1-10, 1981.

15. Inouye, T. A seed-borne mosaic virus of peas. Ann. Phiytopathol. Soc. Jpn. 33:38-42, 1967.

16. Marx, G. A., and R. Provvdenti. Linkage relations of mo Pisum Newsl. 11:28-29, 1979.

17. Mink, G. I., J. Kraft, J. Knesek, and A. Jafrl. A seedborne virus of peas Phytopathology 59.1342-1343, 1969.

18. Musll, M Uber das Vorkommen des Virus des Blattrollens der Erbse in der Slowakei. Biologia (Bratisl.) 21:133-138, 1966.

19. Provvidenti, R. Inheritance of resistance to clover yellow vein virus in Pisum sativum. J. Hered. 78:126128, 1987.

20. Provvidenti, R., M. J. Silbernagel, and W. Y. Wang. Local epidemic of NL-8 strain of bean common mosaic virus in bean fields of western New York. Plant Dis. 68:1092-1094, 1984

21. Schroeder, W T., and R. Provvidenti. Resistance to watermelon mosaic virus 2 in Pisum sativum conditioned by the gene for resistance to bean yellow mosaic virus. Phytopathology 60:1312-1313, 1970.

22. Stevenson, W. R, and D. J. Hagedorn. A new seedborne virus of peas Phytopathology 59:1051-1052, 1969.

23. Stevenson, W. R. and D. J. Hagedorn. Reaction of Pisum sativum to the pea seed-borne mosaic virus. Plant Dis. Rep. 55:408-410, 1971.

24. Yen, E. D., and P. R. Fry. The inheritance of immunity to pea mosaic virus Aust. J. Agr. Res. 7:272$281,1956$. 